\title{
APPLICATION OF GAUSS-MARQUARDT-LEVENBERG METHOD IN THE INVERSION OF RECEIVER FUNCTION IN CENTRAL BRAZIL
}

\author{
Patrícia Fernandes do Nascimento, George Sand França, \\ Lucas Paes Moreira and Mônica G. Von Huelsen \\ Recebido em 23 março, 2011 / Aceito em 15 fevereiro, 2012 \\ Received on March 23, 2011 / Accepted on February 15, 2012
}

\begin{abstract}
Receiver Function studies contribute to the understanding of crustal structure and its evolution by characterizing the internal physical properties of the Earth, such as seismic wave velocity and Poisson ratio. The data inversion technique enables to modeling of crustal structure, seeking a geologically consistent model that provides a quantitative analysis of the related process. The linearized inversion of Gauss-Marquardt-Levenberg method was applied to the Receiver Function synthetic and real data, obtained by geophysical surveys in Central Brazil, using the Parameter Estimation (PEST) software. The Receiver Function inversion was performed varying only $S$ wave velocity parameter. Synthetic data inversion converged and data fitting was optimal when the initial velocity models used were close to the reference model. The inversion results of Receiver Function data, obtained from nine seismographic stations, using models of crustal structure and velocity distribution based on studies of seismic refraction and Receiver Function were deemed reasonable. Crustal mean velocities are compatible with velocity estimates obtained by previous geophysical studies. The inversion method used here is promising for crustal structure investigations, while PEST software proved to be very efficient, enabling inversion control parameter configuration and monitoring of the process by statistical results.
\end{abstract}

Keywords: data inversion, Receiver Function, Central Brazil.

RESUMO. Estudos geofísicos de Função do Receptor contribuem para a compreensão da estrutura e evolução crustal por meio da caracterização das propriedades físicas do interior da Terra, como velocidade da onda sísmica e razão de Poisson. A técnica de inversão de dados possibilita a modelagem da estrutura crustal, buscando um modelo geologicamente consistente e que forneça uma análise quantitativa desse processo. Aplicou-se o método de inversão linearizada Gauss-Marquardt-Levenberg a dados de Função do Receptor sintéticos e reais, obtidos em levantamentos realizados no Brasil Central, utilizando o programa Parameter Estimation (PEST). A inversão da Função do Receptor foi realizada com variação apenas no parâmetro de velocidade da onda $S$. A inversão de dados sintéticos apresentou convergência, além de ótimo ajuste dos dados quando utilizou-se modelos de velocidades iniciais próximos do modelo de referência. Os resultados das inversões dos dados de Função do Receptor, obtidos a partir de nove estações sismográficas, utilizando modelos de estrutura crustal e distribuição de velocidades baseados em estudos de Função do Receptor e sísmica de refração, mostraram-se razoáveis. As velocidades médias crustais são compatíveis com as estimativas de velocidade obtidas por estudos geofísicos anteriores. 0 método de inversão adotado mostrou-se promissor para estudos da estrutura crustal, e o programa utilizado para executar a inversão dos dados revelou-se bastante eficiente, possibilitando a configuração dos parâmetros de controle da inversão e o acompanhamento desse processo por meio dos resultados estatísticos.

Palavras-chave: inversão de dados, Função do Receptor, Brasil Central. 


\section{INTRODUCTION}

Determining the physical properties of the continental crust improves the understanding of its structure and evolution; therefore, geophysical investigations contribute to the knowledge of the deep crustal portions. An elastic wave that propagates from a source within the Earth travels through rocks and structures modifying their characteristics, so that the earthquake recorded by a seismographic station carries all the information about its propagation. The Receiver Function (RF), a technique developed by Langston $(1977,1979)$ to analyze teleseismic signals, is defined as the deconvolution of the radial component with the vertical (Langston, 1979, Owens et al., 1987). This function enables to estimate crustal thickness and $V_{P} / V_{S}$ ratio using the phase differences converted in $S$, further details are given in Owens et al. (1984) and Ammon (1997).

Applying the inversion to the Receiver Function data, it is possible to model the crustal structure and to seek a geologically consistent model that links the physical parameters and gives a quantitative analysis of the process.

This study aims to enhance the understanding of the crustal structure and confirm the inferences made from the extrapolation of the existing Receiver Function and geological data, through direct and inverse modeling of the Receiver Function data obtained in surveys conducted in the central Tocantins Province. The Gauss-Marquardt-Levenberg linearized inversion method will be applied to the Receiver Function sinthetic and real data, using the software Parameter Estimation (PEST, developed by Doherty, 2005).

The test was performed on real data for the stations that belong to USP and UnB/USGS (Fig. 1), located in Central Brazil. Figure 1 shows the boundaries of the study area inserted in the geological context of the Tocantins Province (Almeida et al., 1981) and the directions of present structural features. Seven stations were temporarily set up in the Tocantins Province, with the exception of PP1B station located at the border between this province and the Paraná Basin. The permanent BDFB station is, currently, a primary station (PS07) of the Comprehensive Nuclear-Test-Ban Treaty Organization (CTBTO).

The Tocantins province is delimited on the east by the São Francisco craton, southwest by the Paraná Basin, northwest by the Amazônico craton and north by the Parnaiba Basin. It represents the extensive Neoproterozoic orogen related to the Brasiliana/PanAfricana Orogeny (Pimental et al., 2000) and resulted from the convergence of the Amazonico and São Francisco-Congo cratons and the Paranapanema block, which is currently covered by the Paraná Basin (Pimental et al., 2000; 2004).

\section{Geology and geophysical studies}

The Tocantins Province includes the Araguaia, Paraguay and Brasilia belts. The Araguaia and Paraguay belts occupy the western portion of the province bordering the Amazonico Craton, the Brasilia Belt is located on the eastern part of this province bordering the western bank of the São Francisco craton. Sedimentary deposits of the Paraná and Parnaiba Basin cover, respectively, the southern and northern boundaries of the Province (Fuck et al., 2007), and an important structure consisting of a system of transcurrent shear zones, called Transbrasiliano Lineament traverses the whole province (Cordani et al., 2000). Detailed geological characteristics of each portion of the Tocantins Province are given in Fuck et al. (2009).

Seismic characteristics of the crust are directly related to the tectonic environment. Analysis of the global results of seismic refraction data could establish behavior trends for the structure of the continental crust as a function of thickness and average $V_{p}$ for each geotectonic environment (Holbrook et al., 1992; Christensen \& Mooney, 1995).

Table 1 lists the tectonic environments shield; platform; orogeny; basin; large igneous province and extended crust (Basin et al., 2000; Holbrook et al., 1992).

The interpretation of seismic refraction data of Central Brazil yielded a model of crustal structure defined by three layers with smooth velocity gradient. This study showed that Moho depth varies between 32 and $43 \mathrm{~km}$, and average $V_{P}$ in the crust changes from $6.3 \mathrm{~km} / \mathrm{s}$ below the Goiás Magmatic Arc, up to $6.4 \mathrm{~km} / \mathrm{s}$ under the Goiás Massif and the eastern portion of the Brasilia Belt (Berrocal et al., 2004). A thin crust of approximately $38 \mathrm{~km}$ was detected under the Brasília Belt, while a thicker one, about $42 \mathrm{~km}$ thick, was detected under the Paraná Basin and São Francisco Craton.

The crusts beneath the São Francisco Craton and Goiás Massif were characterized by thicknesses of about 42 and $38 \mathrm{~km}$, respectively. The largest crustal thickness (approximately $43 \mathrm{~km}$ ) was measured below the mobile belt, and the lowest thickness (about $34 \mathrm{~km}$ ) beneath the Goiás Magmatic Arc. The observed $V_{P}$ in the mantle varies between $8.3 \mathrm{~km} / \mathrm{s}$ on the eastern portion and $8.0 \mathrm{~km} / \mathrm{s}$ on the west side of the Province.

\section{GAUSS-MARQUARDT-LEVENBERG METHOD}

The Gauss-Marquardt-Levenberg (Levenberg, 1944; Marquardt, 1963) iterative method provides a numerical solution to the mathematical problems of minimizing generally non-linear least squares function and consists of a refinement of the GaussNewton, which in turn is a variant of Newton's method. 


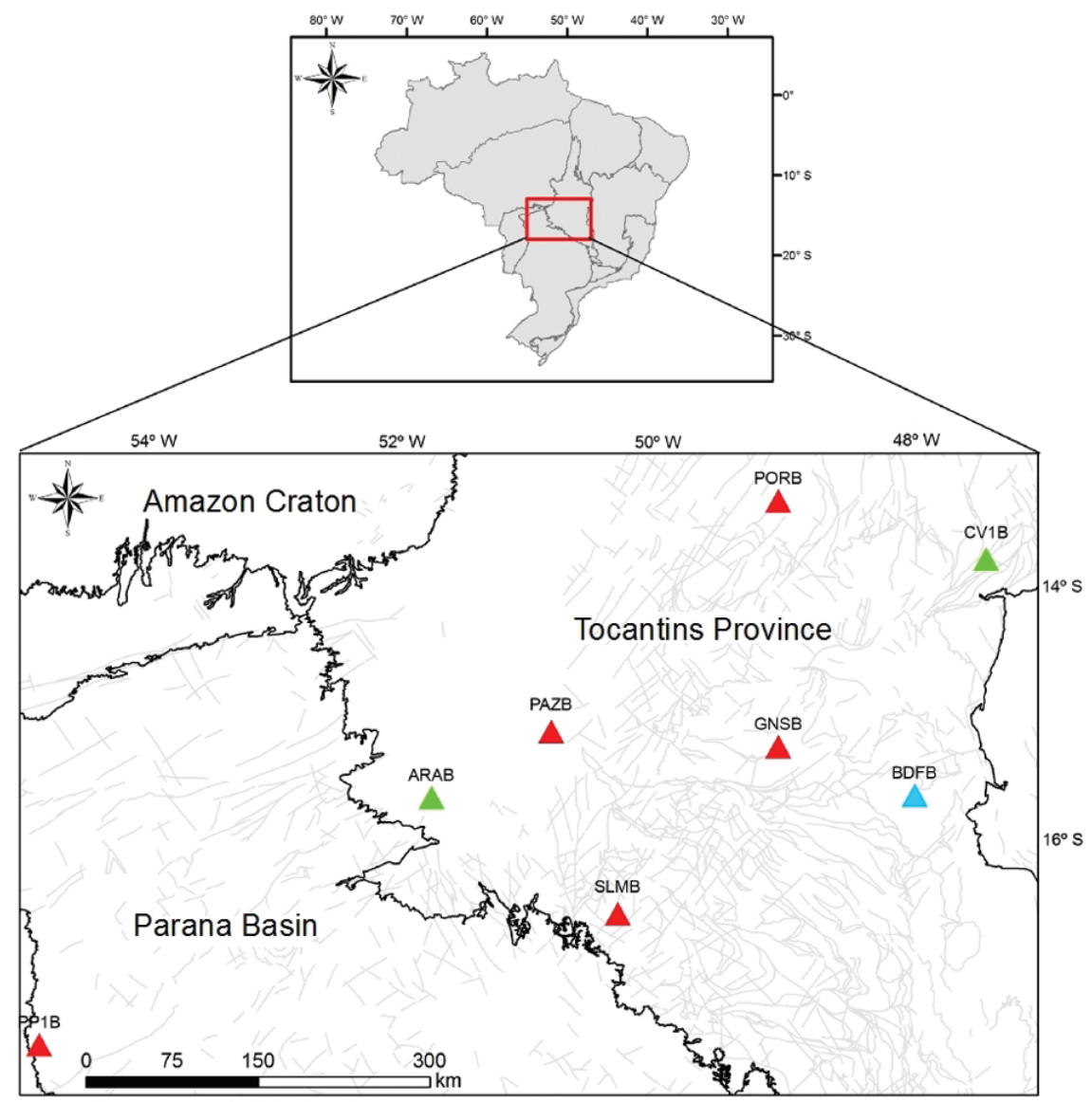

Seismographic Network

$\triangle$ UnB $\triangle$ USGS

USP

Figure 1 - Map of seismographic stations in Central Brazil. The triangles indicate the stations that were used in this paper.

Table 1 - Seismic characteristics of the crust in tectonic areas.

\begin{tabular}{|c|c|c|c|c|c|}
\hline $\begin{array}{c}\text { Tectonic } \\
\text { area }\end{array}$ & $\begin{array}{c}\mathrm{H} \text { average }^{*} \\
(\mathrm{~km})\end{array}$ & $\begin{array}{c}\mathrm{H} \text { modal }^{*} \\
(\mathrm{~km})\end{array}$ & $\begin{array}{c}V_{p} \text { average }^{*} \\
(\mathrm{~km} / \mathrm{s})\end{array}$ & $\left(V_{p} / V_{s}\right)^{\star \star}$ & $\left(V_{p} / V_{s} \text { modal }\right)^{\star *}$ \\
\hline Shield & 41,85 & $40-42$ & $6,2-6,8$ & 1,84 & 1,81 \\
Platform & 41,44 & $42-44$ & $6,4-6.6$ & 1,78 & - \\
Orogen & 42,62 & $36-50$ & $6,4-6,6$ & 1,78 & 1,81 \\
Basin & 43,68 & 40 & - & - & - \\
Igneous Province & 35,46 & 44 & - & - & - \\
Stretched crust & 30,15 & 30 & $6,0-6,6$ & - & - \\
\hline
\end{tabular}

${ }^{\star}$ Compiled from Bassin et al. (2000). ${ }^{\star \star}$ Compiled from Holbrook et al. (1992).

The relationship between the parameters and observations may be linearized by the function $\mathbf{F}(\mathbf{p})$, if the function is continuously differentiable with respect to all $\mathbf{p}$ parameters of the model. The solution is then achieved by minimizing the following function:

$$
\mathbf{d}=\mathbf{F}(\mathbf{p})
$$

where $\mathbf{d}$ is the observed data vector.

The objective function can then be written as follows:

$$
f^{3}=(d-F(p))^{T} *(d-F(p))
$$

Given the initial parameter $p_{0}$, the method produces a series of vectors, $p_{1}, p_{2}, \ldots, p_{n}$, which are expected to converge to $p_{c}$, a local minimum for the $\mathbf{F}(\mathbf{p})$ input function to be fitted. 
Consider the set of initial observations $d_{0}$, generated from the set of parameters $p_{0}$, and the set of observations $\mathbf{d}$ generated by the parameter vector $\mathbf{p}$, which differs from vector $p_{0}$. Expanding $\mathbf{F}(\mathbf{p})$ in a Taylor series gives:

$$
\begin{gathered}
F(p)=F\left(p_{0}\right)+F^{\prime}\left(p_{0}\right)\left(p-p_{0}\right) \\
+F^{\prime \prime}\left(p_{0}\right) / 2 !\left(p-p_{0}\right)^{2}+\cdots+F_{n}\left(p_{0}\right) / n !\left(p-p_{0}\right)^{n}
\end{gathered}
$$

When the difference $\left(p-p_{0}\right)$ is very small, we can neglect terms of order greater than 2, and Eq. (3) is simplified to:

$$
F(p)=F\left(p_{0}\right)+F^{\prime}\left(p_{0}\right)\left(p-p_{0}\right)
$$

Which can be written as:

$$
d=d_{0}+J\left(p-p_{0}\right)
$$

$J$ is a matrix with $m$ rows, where $n$ elements of each row are the partial derivatives of a particular observation with respect to $n$ parameters. $J$ is the Jacobian of the matrix $\mathbf{F}(\mathbf{p})$.

$$
\mathbb{J}(\mathbf{p})=F^{\prime}\left(p_{0}\right)=\left[\begin{array}{cccc}
\frac{\partial F_{1}}{p_{1}} & \frac{\partial F_{1}}{\partial p_{2}} & \cdots & \frac{\partial F_{1}}{\partial p_{n}} \\
\frac{\partial F_{2}}{p_{1}} & \frac{\partial F_{2}}{\partial p_{2}} & \cdots & \frac{\partial F_{2}}{\partial p_{n}} \\
\cdots & \cdots & \cdots & \cdots \\
\frac{\partial F_{m}}{p_{1}} & \frac{\partial F_{m}}{\partial p_{2}} & \cdots & \frac{\partial F_{m}}{\partial p_{n}}
\end{array}\right]
$$

If $p_{c}$ is $F(p)$ local minimum, then it is a critical point and $F^{\prime}\left(p_{c}\right)=0$. Deriving Eq. (4) and equating it to zero, we have:

$$
F^{\prime}\left(p_{0}\right)=F^{\prime \prime}\left(p_{0}\right)\left(p-p_{0}\right)
$$

$F^{\prime \prime}\left(p_{0}\right)$ is known as the square matrix of second-order partial derivatives of function $F\left(p_{0}\right)$, also called the Hessian matrix $(\mathrm{H})$.

From Equations (5) and (7), Eq. (2) can be rewritten as:

$$
f^{3}=\left(d-d_{0}-J\left(p-p_{0}\right)\right)^{T}\left(d-d_{0}-J\left(p-p_{0}\right)\right)
$$

The equation above is minimized iteratively, where the model parameters (elements of vector $\mathbf{p})$ are updated by the $\left(p-p_{0}\right)$ vector based on the $\left(d-d_{0}\right)$ vector, which defines the discrepancy between the values generated by the theoretical model and the experimental observations. Defining $u$ as the update vector of model parameters, Eq. (8) is then rewritten as:

$$
\mathbf{u}=\left(J^{T} J\right)^{-1} J^{T}\left(d-d_{0}\right)
$$

The update vector $u$ should always point to the negative gradient of the objective function in order to reach the function minimum.
Marquardt (1963) suggests adding the a factor (Marquardt coefficient), to the diagonal of the Hessian matrix to stabilize the function. During the iterative process a is to smaller values calculated iteratively to stabilize the inversion. The update vector equation is rewritten as:

$$
\mathbf{u}=\left(J^{T} J+\alpha I\right)^{-1} J^{T}\left(d-d_{0}\right)
$$

where $I$ is the identity matrix. The Marquardt coefficient, $\alpha$, influences both direction and size of iteration step. When $\alpha>0$, the matrix of coefficient $\left(J^{T} J+\alpha I\right.$ ) is positive, and $u$ is negative.

In addition to model convergence to a local minimum, the Gauss-Marquardt-Levenberg inversion method described above provides several statistical parameters that assist in determining the inversion parameters and analyzing the obtained results.

\section{DATA PROCESSING}

\section{Preparation of data for inversion}

The data used in the study were recorded by eight seismographic stations located in the Tocantis Province, spatially arranged as shown in Figure 1.

Data from fifty (50) seismic events with magnitude between 5.0 and $6.75 \mathrm{mb}$ and epicenter distance between $20^{\circ}$ and $80^{\circ}$, of which $80 \%$ were shallow were selected to apply the RF variation of magnitude and of epicenter distance and the seismic events are are from the NW direction, sourced in the convergence zone between the Nazca and South-American plates. Figure 2 shows the earthquake distribution map used for the RF, rosette diagrams and graphs of magnitude, epicenter distance and depth.

The data were filtered using the Gaussian lowpass filter with factor 3, eliminating frequencies higher than $1.5 \mathrm{~Hz}$, except for the data from CORB, GNSB and SLMB stations, which used Gaussian filter with factor 2.5. This filter is typically used to reduce high frequency image noise that affects directly the RF resolution. The water level used was either 0.001 or 0.01 to eliminate white noise, and temporal window between 30 and 110 seconds after direct $P$. This choice took into account the low level of pre-signal noise and coverage of possible $P$ phase converted into $S$ in the Moho. The RF was obtained in the frequency domain (pwavegn software, Ammon 1997).

The crustal thickness and $V_{p} / V_{s}$ ratio values were estimated using the HK-Stacking method (Zhu \& Kanamori, 2000). This procedure discussed by França (2003), França \& Assumpção (2004), Novo Barbosa (2008) and Pavão (2010), maximizes the sum of the amplitudes of the three major phases. The only information needed is the average velocity of $P$ wave in the region. 


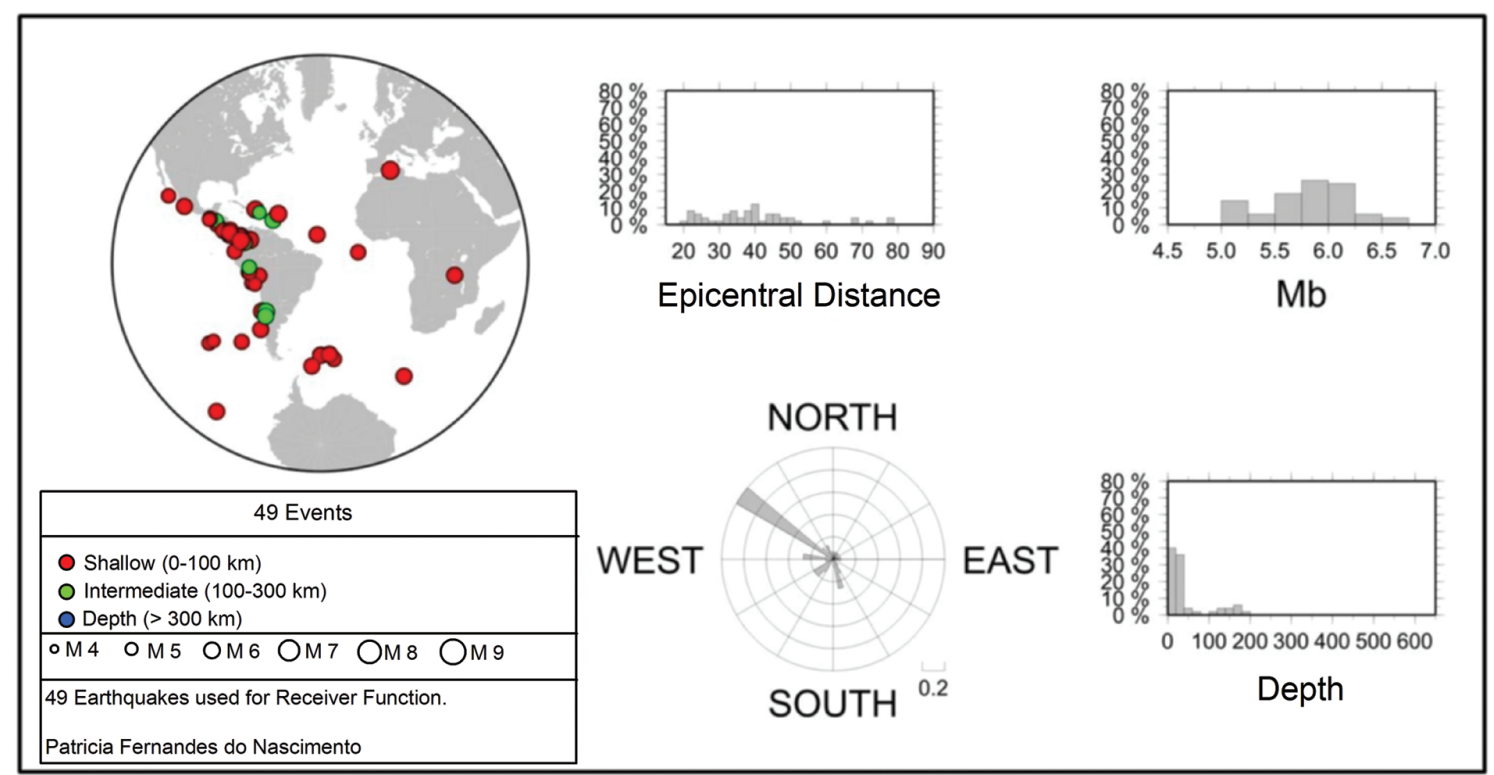

Figure 2 - Left, teleseismic map showing the nine stations that supplied the data used in the Receiver Function. Right, graph showing the epicenter distance, magnitude, rosettes and depth $(\mathrm{km})$.

In this study, the weights were defined according to values suggested by Zhu \& Kanamori (2000): $P_{s}=0.7, P_{p} P_{d s}=0.2$ and $P_{p} S_{d s}+P_{s} P_{d s}=0.1$, so that the lighter $P_{s}$ phase is the most representative in the calculations. The initial $V_{p}$ values were based on the mean $V_{p}$ values in the crust of Central Brazil previously published in related works (Assumpção et al., 2004; Bianchi, 2008).

\section{Data processing for inversion}

Data inversion requires an initial input model; a forward function and experimental data-set (field data or synthetic data). The PEST software used in the inversion allows setting the convergence criterion, maximum allowed iterations and the limit values of model variation. The results of this inversion are available in multiple response files generated by the program, facilitating the analysis. These files display the general result of the process, including mean square residue, covariance and correlation matrices, eigenvectors, eigenvalues and inversion evolution at each iteration. Furthermore, an output file also provides sensitivity degree as a function of both model parameters and each observation.

The RF inversion is a sum of velocity contrasts as a function of depth (Ammon et al., 1990). The RF is mainly influenced by S-wave velocity and layer thickness; therefore, inversion was performed for a defined velocity structure with fixed horizontal layers with varying S-wave velocity only.
The initial velocity model should reflect as closely as possible the structure of crustal velocity below every station. The velocity models obtained from the seismic surveys conducted in Central Brazil (Ventura, 2010) were used for the CV1B and PORB stations. The initial models for the other stations were based on the regional velocity model for Brazil, the BR90 model (Assumpção et al., 2010) (Fig. 3)

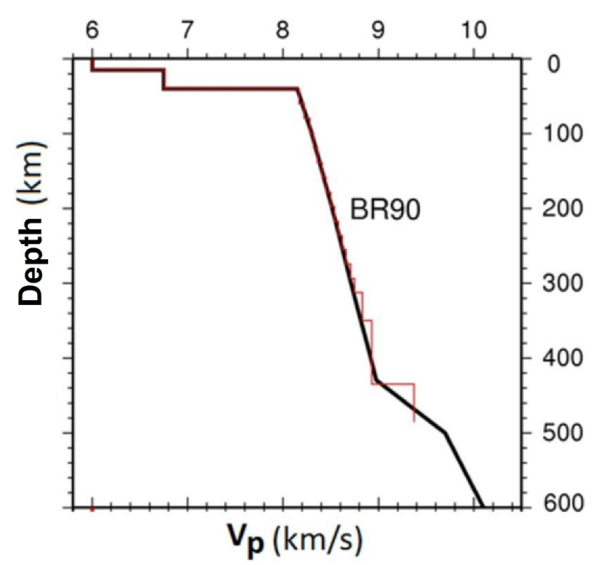

Figure 3 - Regional model BR90 of crustal P wave velocities.

Assuming Poisson's ratio for a solid rock (0.25 equals to $\left.V_{p} / V_{s}=1.73\right)$, density can be approximated by $\rho=$ $0.32 V_{p}+0.77$ (Berteussen, 1977), where $\rho$ is density.

RF inversion was applied to traces with high signal-noise ratio and clear visual identification of $\mathrm{S}$ phases converted from $P$ 
Table 2 - Events used in the receiver function inversion.

\begin{tabular}{|c|c|c|c|c|c|c|c|c|c|c|}
\hline Station & Year & Day & Hour & Min. & Sec. & Lat. & Long. & $m_{b}$ & Dist. $\left(^{\circ}\right)$ & $\mathrm{Az}\left({ }^{\circ}\right)$ \\
\hline ARAB & 1998 & 050 & 04 & 21 & 45 & -10.67 & -74.54 & 5.7 & 22.68 & 279 \\
BDFB & 1995 & 019 & 15 & 05 & 03 & 5.11 & -72.91 & 6.4 & 32.14 & 308 \\
CV1B & 2003 & 265 & 04 & 45 & 36 & 19.84 & -70.66 & 6.2 & 40.55 & 325 \\
GNSB $^{\star}$ & 2002 & 219 & 23 & 59 & 14 & 7.80 & -82.66 & 5.6 & 40.40 & 302 \\
GNSB $^{\star}$ & 2002 & 212 & 00 & 16 & 45 & 7.98 & -82.78 & 5.9 & 40.60 & 302 \\
GNSB $^{\star}$ & 2002 & 167 & 02 & 46 & 13 & 8.74 & -84.02 & 5.4 & 42.04 & 302 \\
PAZB $^{\star}$ & 2001 & 237 & 02 & 02 & 02 & 7.58 & -82.63 & 5.9 & 38.75 & 303 \\
PAZB $^{*}$ & 2002 & 219 & 23 & 59 & 14 & 7.80 & -82.66 & 5.6 & 38.89 & 304 \\
PAZB $^{\star}$ & 2002 & 212 & 00 & 16 & 45 & 7.98 & -82.78 & 5.9 & 39.10 & 304 \\
PAZB $^{\star}$ & 2001 & 106 & 21 & 54 & 01 & 13.24 & -91.19 & 5.1 & 48.87 & 303 \\
PAZB $^{\star}$ & 2001 & 332 & 14 & 32 & 33 & 15.57 & -93.10 & 5.7 & 51.70 & 304 \\
PORB $^{2001}$ & 237 & 02 & 02 & 02 & 7.58 & -82.63 & 5.9 & 39.27 & 300 \\
PP1B $^{2002}$ & 319 & 13 & 05 & 40 & -55.64 & -35.66 & 5.9 & 40.70 & 163 \\
SLMB & 2001 & 313 & 00 & 47 & 58 & 9.64 & -82.24 & 5.9 & 40.92 & 307 \\
\hline
\end{tabular}

*Stacked events.

in the Moho. The events used in the inversion process are shown in Table 2. Each sample of RF trace is interpreted as a different observation, and it is necessary to assign a weight to each one of these observations. The weights are used to estimate the parameters and assigned to the residuals to calculate the objective function, thus discriminating the degree of uncertainty associated with each data. Therefore, greater weight should be assigned to the most reliable measurements, which in this case are the $P$ phases converted to $S$ in the Moho bearing crustal structure information.

The weight values assigned to the samples relative to $P_{s}$ and multiples selected from tests, whose criteria were the high data correlation and the waveform data fitting.

At each iteration of the inversion, new $V_{s}$ value is incorporated into the calculation of the new velocity model, from which new data (synthetic RF) and residues are produced. This process continues until the misfit between the observed (observed RF) and calculated (synthetic RF) is minimum.

The synthetic RF was obtained, first by generating a synthetic triaxial seismogram using the Kennett reflection matrix (1983) given by the respknt software, available from Ammon (1997). The deconvolution of the synthetic seismogram was performed by the sacdecon software, developed by Herrmann \& Ammon (2002), based on the iterative method in the frequency domain (Ligorría \& Ammon, 1999).

\section{RECEIVER FUNCTION ANALYSIS}

Figure 4 shows RF traces arranged according to epicenter distance $\left(^{\circ}\right)$ for PP1B station. The stations had nine traces aver- age, and the azimuthal distribution of events is predominantly SE/NW. Some traces from PAZB and GNSB were stacked to decrease signal-noise ratio. The $P_{S}$ phase is evident in all traces, and there is an alignment phase corresponding to $P_{p} P_{d s}$ multiple reflections in the BDFB, PP1B and PORB stations; however, the traces of stations CV1B, SLMB and ARAB had a low signal-noise ratio, hindering the identification of multiple reflections. To estimate crustal thickness and $V_{p} / V_{s}$ ratio we used the HK-Stacking technique (Zhu \& Kanamori, 2000) (Fig. 5). Tables 3 and 4 show the values obtained for $V_{p} / V_{s}$ ratio and crustal thickness, respectively, in this study and the works of Assumpção et al. (2004), Bianchi (2008), Lloyd et al. (2010) and Soares et al. (2006).

The estimates given by Assumpção et al. (2004) and Bianchi (2008) are based on the analysis of RF traces obtained using the software PWSS (Schimmel \& Paulssen, 1997) and HK-Stacking (Zhu \& Kanamori, 2000), respectively. Lloyd et al. (2010) used joint inversion of surface waves and RF, while Soares et al. (2006) used seismic refraction method and Receiver Function.

The values of $V_{p} / V_{s}$ ratio and crustal thickness given by the Receiver Function analysis, at this stage, are coherent with the data already published in studies of the region. One exception was PAZB station whose data yielded high $V_{p} / V_{s}$ ratio $(1.80 \pm 0.02 \mathrm{~km} / \mathrm{s})$ and crustal thickness $(37.7 \pm 0.8 \mathrm{~km})$ higher than the reference values. The identification of $P_{p} P_{d s}$ and $P_{p} S_{d s}+P_{s} P_{d s}$ multiple reflections, given by HK-Stacking in the RF traces may have caused this difference. However, crustal thickness beneath this station is close to the value obtained for PORB station, also located in the upper portion of the Goiás Magmatic Arc. 


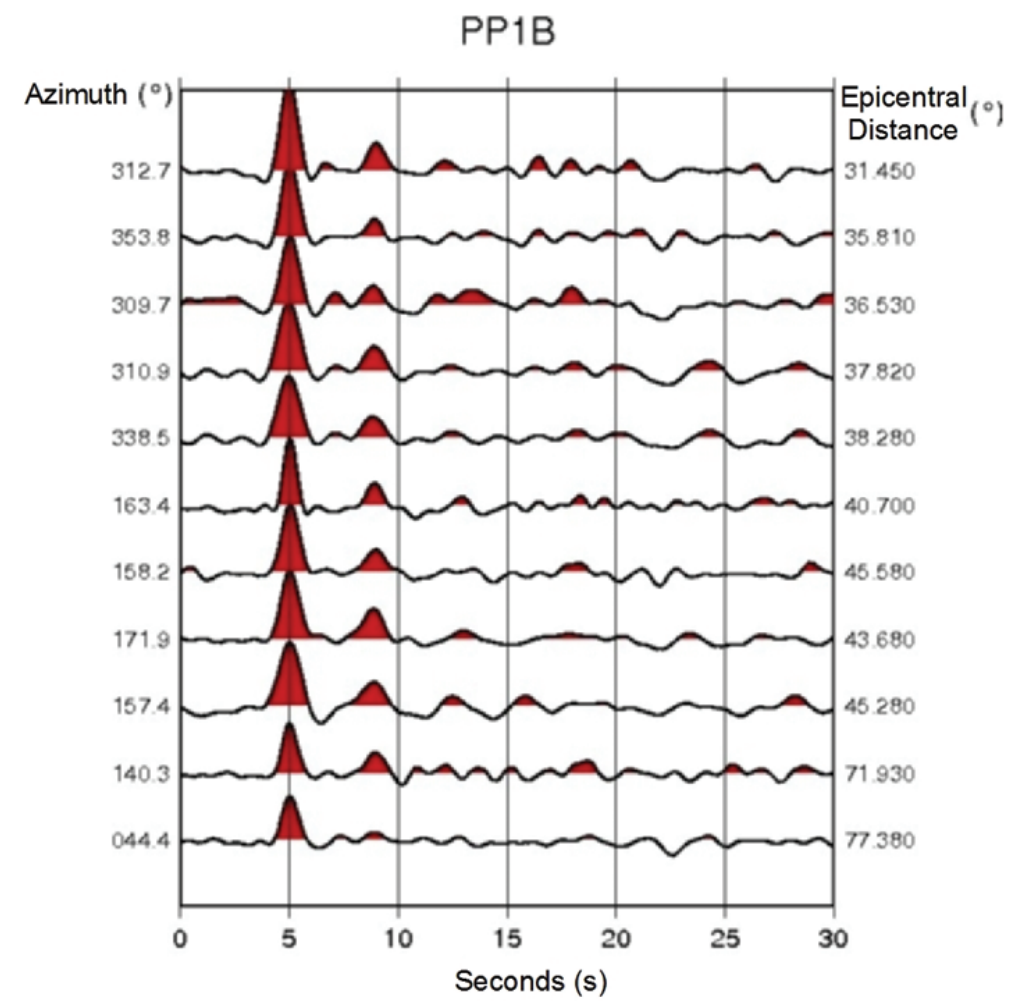

Figure 4 - Receiver Function for PP1B station.

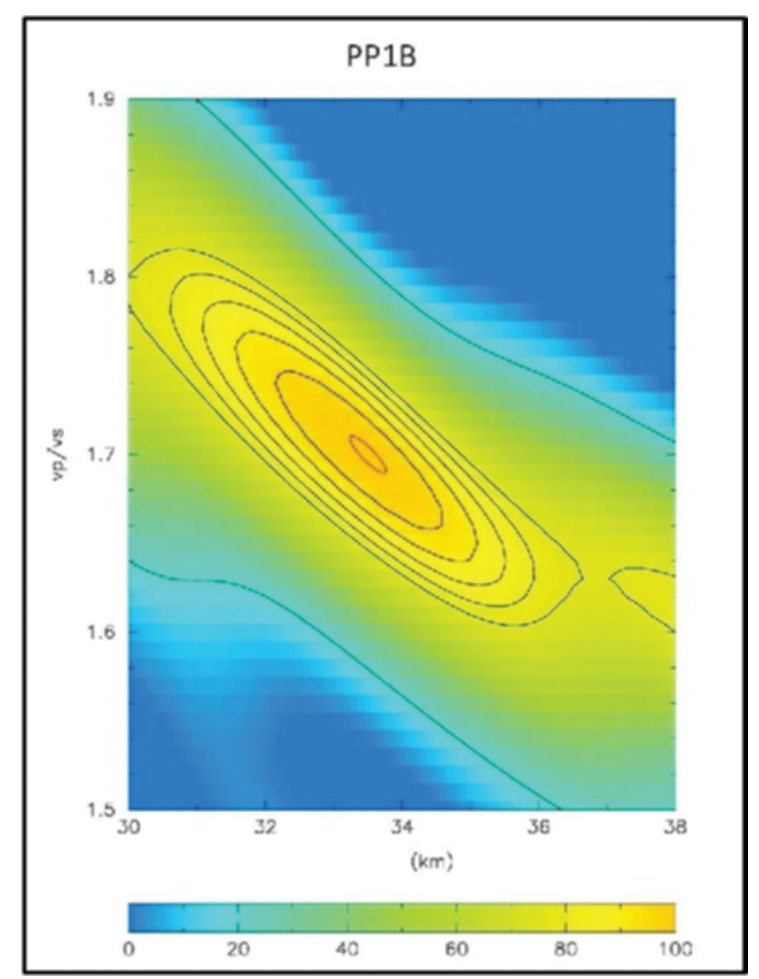

Figure 5 - Plot of $V_{p} / V_{s}$ ratio versus crustal thickness for PP1B station generated by HK-Stacking software. The color scale represents the correlation degree between two variables in percentages. 
Table 3 - Compilation of $V_{p} / V_{s}$ ratio estimates obtained by geophysical studies performed in Central Brazil. The $V_{P}$ adopted in our study was $6.3 \mathrm{~km} / \mathrm{s}$ for BDFB GNSB stations and $6.4 \mathrm{~km} / \mathrm{s}$ for the others.

\begin{tabular}{|c|c|c|c|c|c|}
\hline & $\begin{array}{c}\text { Data obtained } \\
\text { in this study }\end{array}$ & $\begin{array}{c}\text { Assumpção et al. } \\
(2004)\end{array}$ & $\begin{array}{c}\text { Bianchi } \\
(2008)\end{array}$ & $\begin{array}{c}\text { Lloyd et al. } \\
(2010)\end{array}$ & $\begin{array}{c}\text { Soares et al. } \\
(2006)\end{array}$ \\
\hline Station & $V_{p} / V_{s}$ & $V_{p} / V_{s}$ & $V_{p} / V_{s}$ & $V_{p} / V_{s}$ & $V_{p} / V_{s}$ \\
\hline ARAB & $1,77 \pm 0,03$ & - & - & $1,76 \pm 0,03$ & - \\
BDFB & $1,68 \pm 0,03$ & $1,70 \pm 0,01$ & - & - & - \\
CV1B & $1,70 \pm 0,04$ & - & $1,66 \pm 0,04$ & - & 1,69 \\
GNSB & $1,71 \pm 0,03$ & $1,72 \pm 0,01$ & $1,69 \pm 0,01$ & - & - \\
PAZB & $1,80 \pm 0,02$ & $1,76 \pm 0,01$ & $1,75 \pm 0,03$ & - & - \\
PORB & $1,75 \pm 0,03$ & $1,75 \pm 0,02$ & $1,74 \pm 0,01$ & - & $1,72 \pm 0,02$ \\
PP1B & $1,70 \pm 0,02$ & - & $1,70 \pm 0,01$ & $1,71 \pm 0,02$ & - \\
SLMB & $1,74 \pm 0,02$ & $1,74 \pm 0,01$ & $1,73 \pm 0,01$ & - & - \\
\hline
\end{tabular}

Table 4 - Compilation of crustal thickness obtained by geophysical studies performed in Central Brazil.

\begin{tabular}{|c|c|c|c|c|c|}
\hline & $\begin{array}{c}\text { Data obtained } \\
\text { in this study }\end{array}$ & $\begin{array}{c}\text { Assumpção et al. } \\
(2004)\end{array}$ & $\begin{array}{c}\text { Bianchi } \\
(2008)\end{array}$ & $\begin{array}{c}\text { Lloyd et al. } \\
(2010)\end{array}$ & $\begin{array}{c}\text { Soares et al. } \\
(2006)\end{array}$ \\
\hline Station & $\mathrm{H}(\mathrm{km})$ & $\mathrm{H}(\mathrm{km})$ & Thickness $(\mathrm{km})$ & $\mathrm{H}(\mathrm{km})$ & $\mathrm{H}(\mathrm{km})$ \\
\hline ARAB & $31,7 \pm 1,0$ & - & - & $29,6 \pm 1,3$ & - \\
BDFB & $42,0 \pm 1,6$ & $41,9 \pm 0,8$ & - & - & - \\
CV1B & $40,5 \pm 1,4$ & - & $41,8 \pm 1,9$ & - & $39.5^{*}$ \\
GNSB & $42,1 \pm 1,2$ & $42,6 \pm 0,9$ & $42,9 \pm 0,3$ & - & - \\
PAZB & $37,7 \pm 0,8$ & $33,2 \pm 0,4$ & $33,3 \pm 1,3$ & - & - \\
PORB & $36,8 \pm 0,7$ & $37,1 \pm 0,9$ & $36,8 \pm 0,5$ & - & $37,6^{\star}$ \\
PP1B & $33,5 \pm 0,5$ & - & $33,3 \pm 0,2$ & $33,3 \pm 0,8$ & - \\
SLMB & $32,8 \pm 0,9$ & $33,0 \pm 0,7$ & $33,3 \pm 0,5$ & - & - \\
\hline
\end{tabular}

*Obtained by average thickness of RF traces.

\section{INVERSION OF RECEIVER FUNCTION}

\section{Synthetic}

Several tests were conducted with the synthetic data (Fig. 6) in order to check the effectiveness of the software used for the inversion, the convergence of the modeled data and the influence of the factors on the inversion process. The synthetic data were generated from a velocity model based on a crust with three 11-km-thick layers and mean $V_{p} / V_{s}$ ratio of 1.74 , whose velocity distribution is based on the regional crustal velocity model for Brazil (model BR90). Since this is a linearized version, it is important to use different initial models to test the effectiveness of the inversion, that is, how changing the initial model affects the final model.

For the four initial models tested, $V_{p} / V_{s}$ ratio of each layer remained constant while only $S$ wave velocity varied. The initial model 1 contains values close to the reference model, which was used to generate the synthetic trace, while models 2, 3 and 4 dis- play more discrepant velocity values. Figures 6 to 9 show the results of the inversion of the initial models tested.

The test showed that the inversion is efficient, converging and the waveforms adjust to the phases $P, P_{S}$, and multiple reflections, and this can be seen by the high correlation index of the data (Table 5).

Table 5 - Results for the inversion of the Synthetic Receiver Function.

\begin{tabular}{|c|c|c|c|}
\hline model & correlation & $\begin{array}{c}V_{s}^{*} \text { average } \\
(\mathrm{km} / \mathrm{s})\end{array}$ & $\begin{array}{c}V_{s}^{*} \text { average } \\
(\mathrm{km} / \mathrm{s})\end{array}$ \\
\hline reference & - & 6,41 & 3,68 \\
model 1 & 0,9876 & 6,43 & 3,69 \\
model 2 & 0,9642 & 6,32 & 3,62 \\
model 3 & 0,9978 & 6,41 & 3,68 \\
model 4 & 0,9073 & 6,23 & 3,58 \\
\hline
\end{tabular}

The better the fitting between observed and calculated signals the closer the final velocity models are to the reference model 

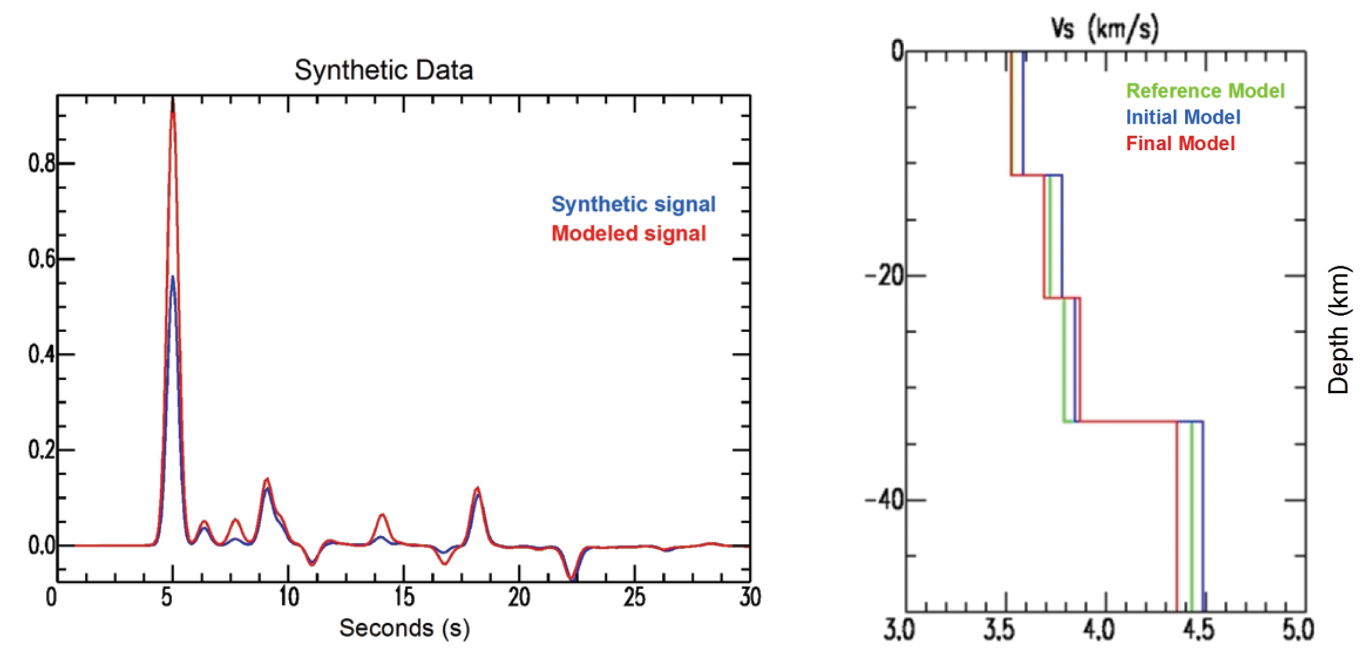

Figure $\mathbf{6}$ - Inversion of synthetic data using initial model 1. a) fitting of the waveform of RF. The blue line represents the synthetic data and the red line represents the modeled data b) Crustal $S$ wave velocity model. The blue line represents the initial model; the red, the final model after the inversion; and the green, the reference model that generated the synthetic data.
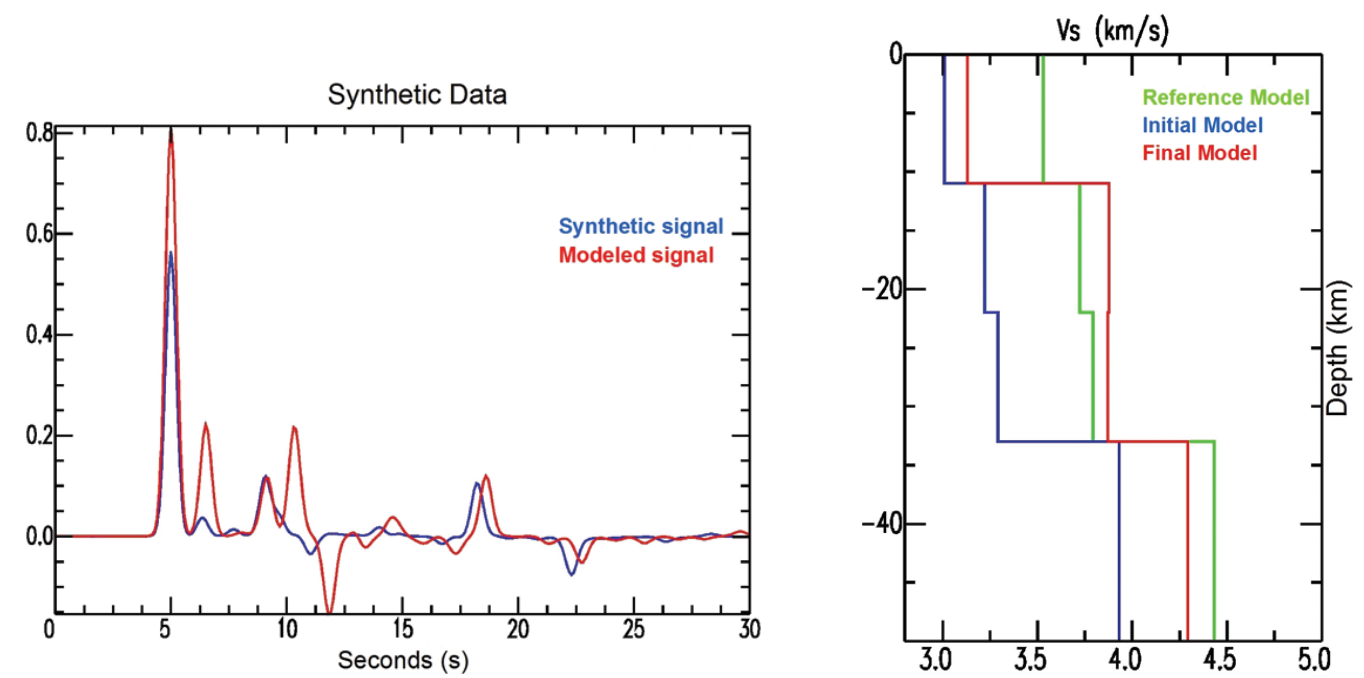

Figure 7 - Inversion of synthetic data using initial model 2. a) fitting of the waveform of RF. The blue line represents the observed data and the red line represents the modeled data. b) Crustal $\mathrm{S}$ wave velocity model. The blue line represents the initial model; the red, the final model after the inversion; and the green, the reference model that generated the synthetic data.

generated from the synthetic data. The best results were achieved by inversion of models 1 and 3 , where correlation indices were higher and had the best fitting between observed and calculated waveform data, and the final velocity distribution model most compatible with the reference model. The mean crustal $V_{s}$ and $V_{p}$ are compatible with the reference values, with the exception of inversion of models 2 and 4 , which are not as efficient.

Despite the fact that in some cases the $V_{S}$ value found for determined layers differs from reference values, the inversion of $\mathrm{RF}$ converges to reasonable average crustal velocity values. Thus,
RF inversion methodology yields reasonable distribution models for average crustal velocity.

\section{Real data}

The inversion was then applied to RF traces obtained from the records of stations located in Central Brazil. These signals provide information about the $S$ speed structure of the lithosphere below the stations.

Two different initial models were used for data inversion of each station. The initial model 1 was based on the crustal speed 

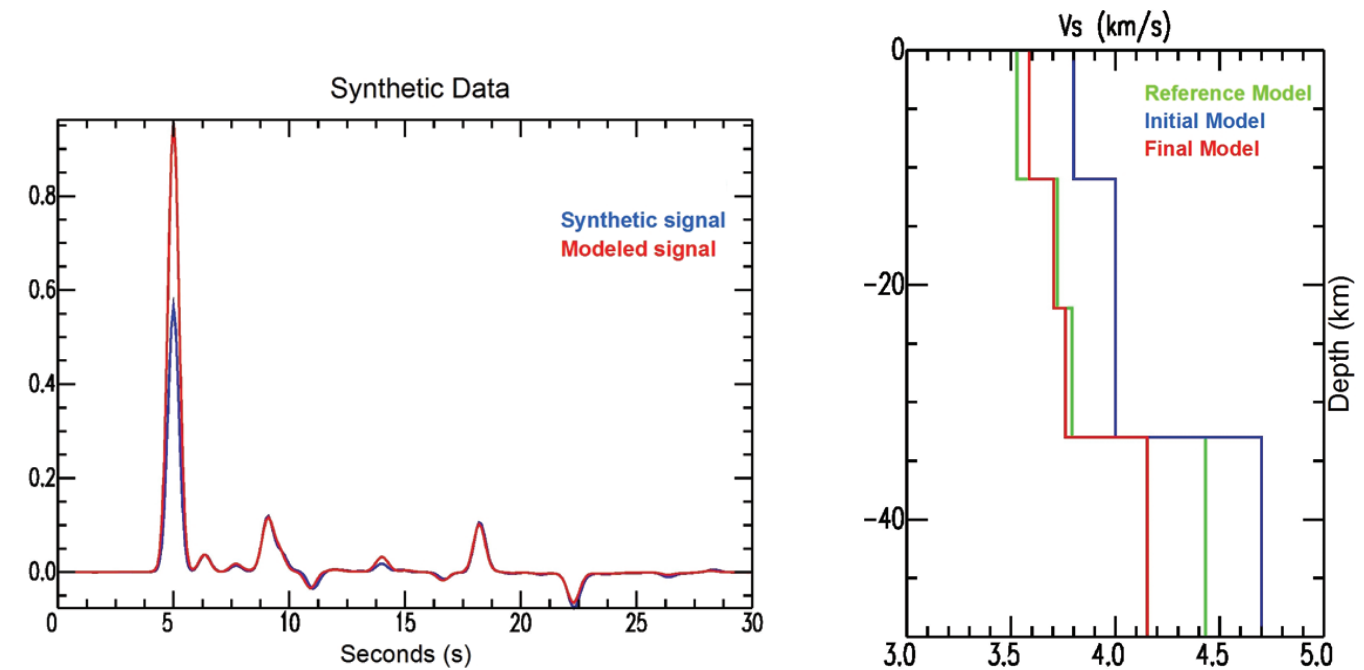

Figure 8 - Inversion of synthetic data using initial model 2. a) fitting of the waveform of RF. The blue line represents the synthetic data; and the red line represents the modeled data. b) Crustal $\mathrm{S}$ wave velocity model. The blue line represents the initial model; the red, the final model after inversion; and the green, the reference model that generated the synthetic data.
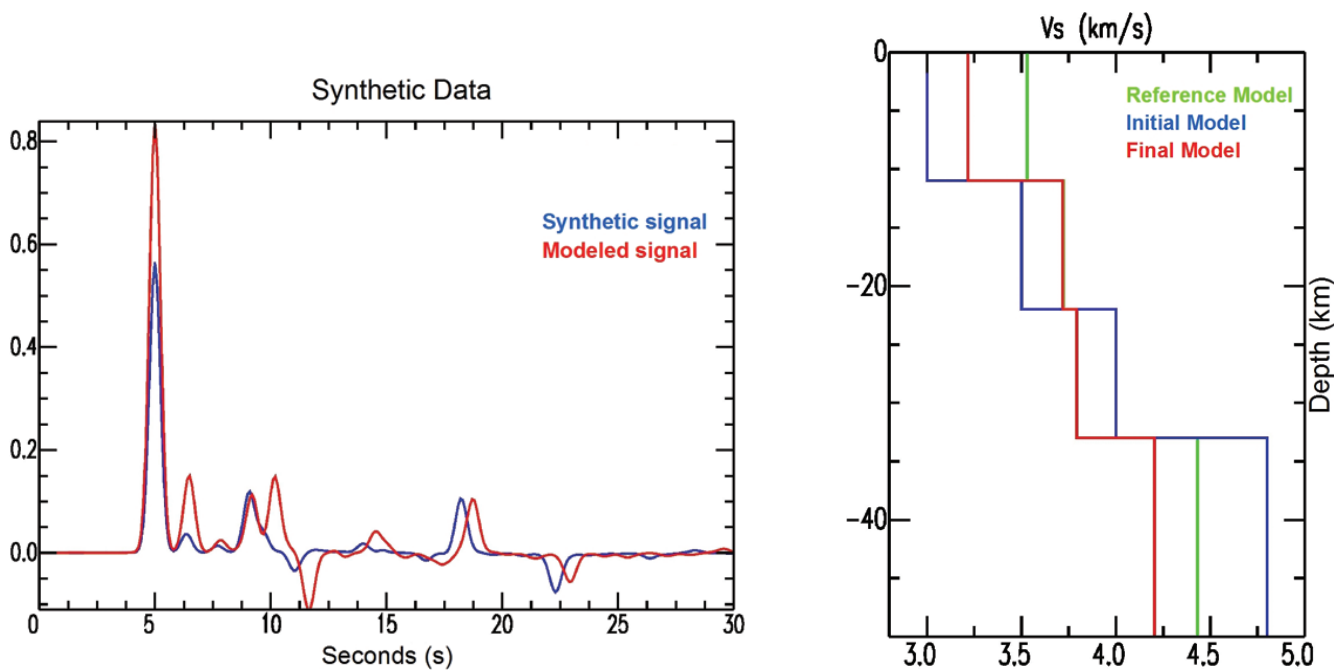

Figure 9 - Inversion of synthetic data using initial model 2. a) Fitting of the waveform of RF. The blue line represents the synthetic data; and the red line represents the modeled data. b) Crustal $\mathrm{S}$ wave velocity model. The blue line represents the initial model; the red, the final model after inversion; and the green, the reference model that generated the synthetic data.

model (model BR90), which considers average $V_{p} / V_{s}$ equals to 1.74 in the crust and 1.85 in the mantle; while initial model 2 was based on the average $V_{p} / V_{s}$ values given by the RF analysis using the HK-Stacking software for each station. For the CV1B and PORB stations, the inversion was performed by a third initial model of velocities based on seismic refraction surveys conducted in the study area (Ventura, 2010). Table 6 and Figures 10 and 11 show the inversions performed by the Gauss-MarquardtLevenberg method for station PP1B. Figure 12 shows the sensitivity data plot for station PP1B.
The ARAB station did not show a clear phase alignment in the RF multiple reflections, hindering its identification. Therefore, due to the uncertainty on position of these phases, greater weight was assigned to $P_{S}$ phase only, which resulted in a sensitivity peak and fitting of the calculated with respect to observed waveform data for this phase only. For the BDFB station, although model 2 presents an estimate of seismic velocity geologically consistent, the inversions were not adjusted for crustal phases, unlike model 1. In CV1B, the three inversions performed fit the data set corresponding to the $P_{S}$ phase, and apparently the 
Table 6 - Average crustal velocities of $\mathrm{P}$ and $\mathrm{S}$ waves $(\mathrm{km} / \mathrm{s})$ and data correlation after inversion.

\begin{tabular}{|c|c|c|c|c|c|c|c|c|c|c|c|c|}
\hline \multirow{2}{*}{ Station } & \multicolumn{4}{|c|}{ model 1} & \multicolumn{4}{c|}{ model 2} & \multicolumn{3}{c|}{ model 3} \\
\cline { 2 - 13 } & $V_{p}$ & $V_{s}$ & Cor & $V_{p} / V_{s}$ & $V_{p}$ & $V_{s}$ & Cor & $V_{p} / V_{s}$ & $V_{p}$ & $V_{s}$ & Cor & $V_{p} / V_{s}$ \\
\hline ARAB & 5,9 & 3,4 & 0,99 & 1.74 & 6,3 & 3,5 & 0,99 & 1,77 & & & & \\
BDFB & 6,7 & 3,9 & 0,90 & 1.74 & 6,2 & 3,7 & 0,90 & 1,68 & & & & \\
CV1B & 6,6 & 3,8 & 0,84 & 1.74 & 6,3 & 3,7 & 0,86 & 1,70 & 5,6 & 3,4 & 0,87 & 1,68 \\
GNSB & 6,4 & 3,7 & 0,86 & 1.74 & 6,3 & 3,7 & 0,90 & 1,71 & & & & \\
PAZB & 6,8 & 3,8 & 0,82 & 1.74 & 7,2 & 3,9 & 0,76 & 1,80 & & & & \\
PORB & 6,3 & 3,6 & 0,82 & 1.74 & $=$ & $=$ & $=$ & $=$ & 5,6 & 3,3 & 0,82 & 1,68 \\
PP1B & 6,5 & 3,7 & 0,92 & 1.74 & 6,5 & 3,7 & 0,82 & 1,77 & & & & \\
SLMB & 6,3 & 3,6 & 0,92 & 1.74 & $=$ & $=$ & $=$ & $=$ & & & & \\
\hline
\end{tabular}
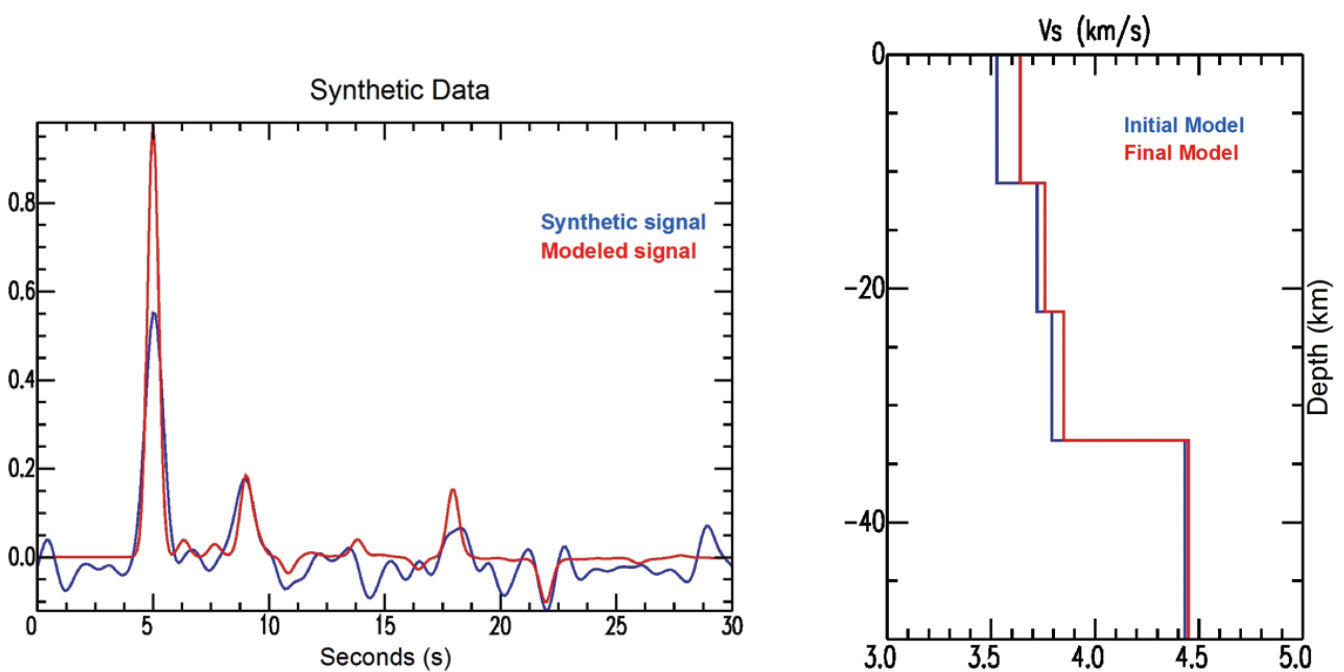

Figure 10 - Inversion of synthetic data for PP1B station using the initial model 1. a) Fitting of the waveform of RF. The blue line represents the observed data and the red line represents the modeled data. b) Crustal $S$ wave velocity model. The blue line represents the initial model; the red, the final model after the inversion; and the green, the reference model that generated the synthetic data.

inversions for the 1 and 2 initial models suggest the locations of multiple reflections approximately 11 and 16 seconds after the arrival of direct $P$, despite having relatively low sensitivity for the samples corresponding to $P_{S}$ and multiple phases. This is due to the fact that the weight given to these phases is not much greater than the weight assigned to the other trace samples. The inversion using model 2 was more consistent with previous works.

The inversion of the RF for the GNSB station fitted the waveform in $P, P_{s}$ and multiple phases. The modeled data displayed low residue compared to the observed data and to multiple reflections of the $S$ wave. Both inversions are compatible with results already obtained, while the sensitivity curve in relation to the observations peaked for $P_{S}$ and multiple phases. For PAZB station, data fitting given by inversion of model 2 is incipient in the crustal phases, compared to the fitting given by inversion of model 1 , the sensitivity curve peaks for crustal phase samples, the values estimated by the inversion are inconsistent with previous work.

As for PORB station, the fitting of 1 and 2 initial models was the same, and therefore, model 3 (seismic) was used. The inversions fitted the crustal phase data; however, it showed low sensitivity for the data in general, while inversion using model 1 displayed results more consistent with previous work.

The inversion of RF for PP1B station yielded good fitting for the waveform, mainly for the $P, P_{s}$ and multiple reflection phases, as well as inversion sensitivity to the observations, which is also higher in these phases, for both cases. The inversions of models 1 and 2 yielded correlation coefficients of 0.92 and 0.95 , respectively, which suggests a strong correlation between the $\left(V_{S}\right)$ parameters of the model, while both inversions were consistent. For the SLBM station, only the inversion of initial 

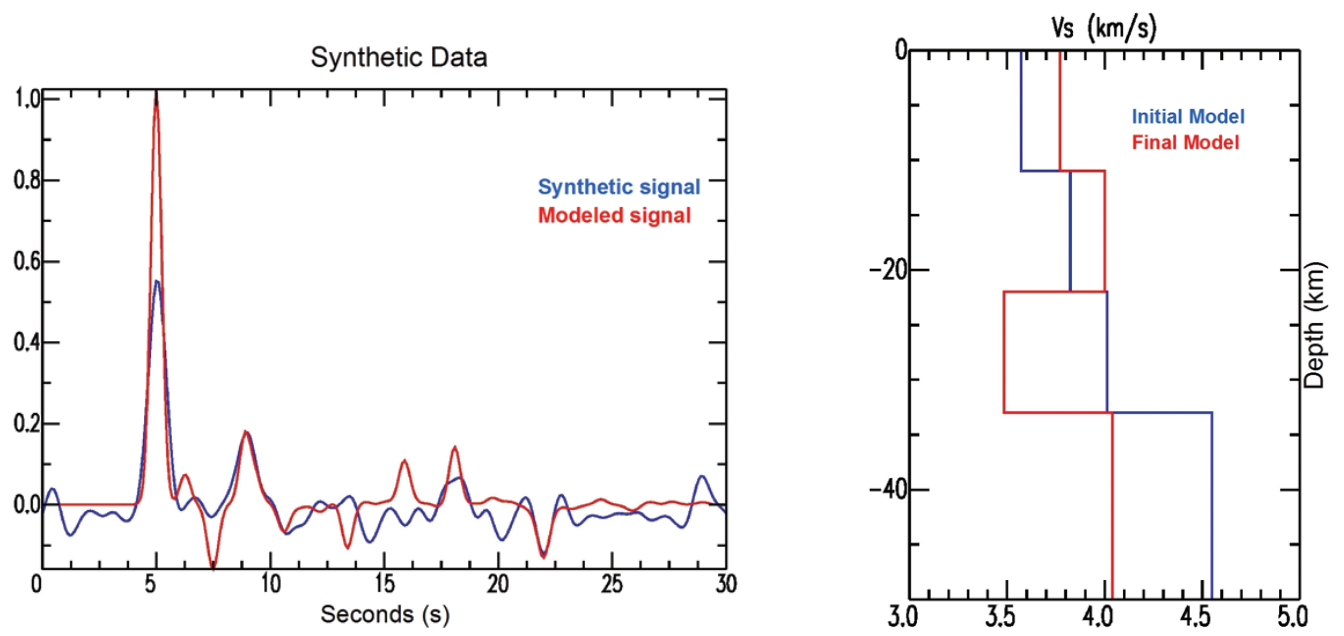

Figure 11 - Inversion of synthetic data for PP1B station using initial model 1. a) Fitting of the waveform of RF. The blue line represents the observed data and the red line represents the modeled data. b) Crustal $S$ wave velocity model. The blue line represents the initial model; the red, the final model after the inversion; and the green, the reference model that generated the synthetic data.

model $1\left(V_{p} / V_{s}=1.74\right)$ was performed, since the HKStacking software output did not yield different value for the $V_{p} / V_{s}$ ratio. The RF traces for this station were not aligned in the phase of multiple reflections. Due to uncertainty about the location of these phases, greater weight was assigned only to $P_{S}$ phase, which resulted in a sensitivity peak and optimal fitting of the calculated and observed waveform data only for this phase, and a correlation index of 0.92 after inversion.

\section{DISCUSSION AND CONCLUSIONS}

RF tests using synthetic data displayed the expected convergence for the inversion of initial models built with values close to the reference model, while also providing good fitting between the observed and calculated data, thus ensuring the validity of the inversion methodology used for crustal modeling. Most stations displayed good fitting for the observed and modeled data in the $P_{S}$ phase, while for the other analyzed phases, the fitting varied according to the studied station.

The inversion of the RF using real data performed by initial model 1 , built based on the regional distribution model of crustal velocities (model BR90), yielded a better fitting than the inversion of initial model 2 based on the $V_{p} / V_{s}$ ratio estimated by the HK-Stacking software; however, average crustal $V_{p}$ value was high for some stations. On the other hand, the average crustal values for $V_{p}$ and $V_{s}$ are more compatible with velocity estimated in previous geophysical studies (Tables 3 and 4). In some cases, the inversion using both initial models displayed anomalous layers with low crustal velocity. The result of the inversions of initial model 3, built from seismic refraction models did not fit adequately the observed and calculated data, although this initial model is geologically consistent. But, because the inversion method is linearized, it does not solve the convergence problem of the objective function to a local minimum and there could be more than one solution that satisfies the data and fit the criteria. The choice of initial model that theoretically reflects the subsurface crustal structure does not guarantee the convergence of the solution.

The correlation coefficient is closely related to the fitting of the samples, to which we assigned weight in the inversion. The sensitivity of the inversion with respect to observations is influenced by the weight assigned to each sample. This is shown by the sensitivity curves obtained, which peaked for $P_{S}$ and multiple reflection phases when they were identified, thus suggesting greater participation of these samples in the process of parameter estimation. When the weight given to these phases is much higher than the weight assigned to the other samples, the sensitivity peak is also much higher than the amplitudes reached by the remainder of the curve, and when the weight difference is small the sensitivity peak is also smaller.

Considering that we assumed constant $V_{p} / V_{s}$ ratio during the inversion process, the high contrasts obtained for $S$ wave velocities also imply in high contrast for $P$ wave velocity, which should not occur because $S$ wave varies more across the lithosphere compared to $P$ wave (Zandt \& Ammon, 1995). Therefore, it is plausible and recommended the inclusion of the $V_{p} / V_{s}$ ratio as a parameter in the inversion process in order to evaluate the results. 

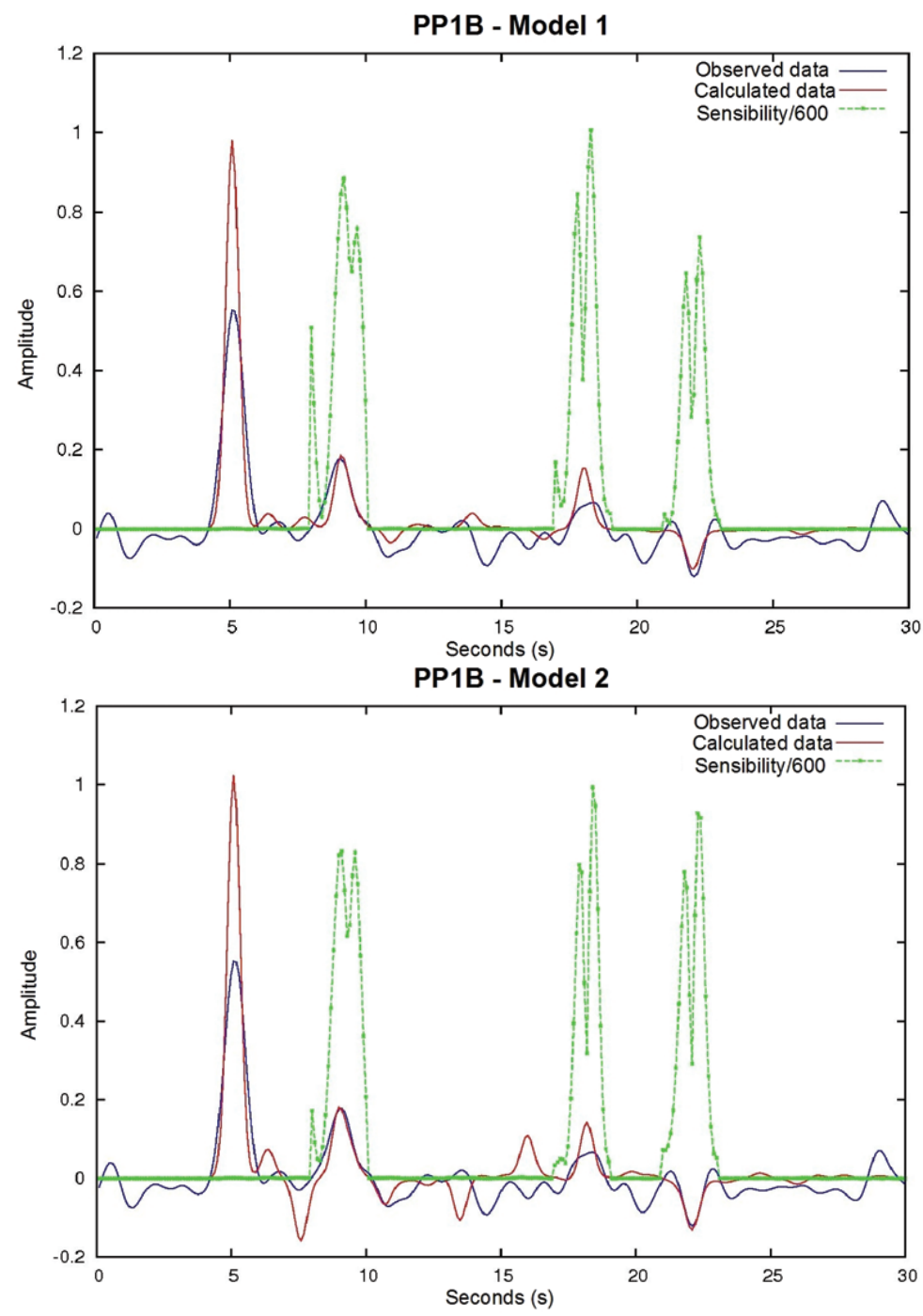

Figure 12 - Sensitivity curve for the inversion of PP1B data using initial model 1 on the left; and initial model 2, on the right. The blue line represents observed data; the red, modeled data; and the green, sensitivity curve inversion.

The inversion method shows potential to study the crustal structure. The ambiguity of the results can be reduced by using joint inversion of different parameters or adding databases from different geophysical methods.

In this study, we performed the inversion of the seismic wave velocity parameter for the RF data. However, the thickness of the crust and of each layer, which make up the adopted structural model, may affect the inversion results. Further detailed analysis is, therefore, recommended to observe the extent of adopted thickness influence on the initial inversion model and if it is possible to insert this parameter in the inversion process.

The PEST software used to invert the data was very efficient, and it allowed setting the parameters to control inversion and to follow the inversion process through statistical results. Its versatility makes it a good choice for modeling joint inversion.

\section{ACKNOWLEDGMENTS}

The authors thank Guilherme Sousa Rocha and José Oswaldo Araújo Filho for the valuable discussions which greatly contributed to this work. Thanks are also due to IAG/USP for releasing the data and to Cesar Garcia Pavão for making the maps. GS França is grateful to CNPq for the research grant (PQ-CNPq, no. 303529/2010-5) and PF Nascimento thanks CNPq for the financial support (Project 553195/2009-3). Maps were generated using GMT (Wessel \& Smith, 1991) and the seismograms were analyzed using SAC (Goldstein et al., 2003). 


\section{REFERENCES}

ALMEIDA FFM, HASUI Y, BRITO NEVES BB \& FUCK RA. 1981. Brazilian structural provinces: an introduction. Earth Sciences Reviews, 17: 1-29.

AMMON CJ, RANDALL GE \& ZANDT GF. 1990. On the non-uniqueness of receiver functions inversions. J. Geophys. Res., 95(B10): 1530315318. doi: 10.1029/JB095iB10p15303.

AMMON CJ. 1997. An overview of Receiver-Function Analysis. Available on: <http://eqseis.geosc.psu.edu/cammon/HTML/RftnDocs/rttn01.html>. Access on: Dec. 2011.

ASSUMPÇÃO M, AN M, BIANCHI M, FRANÇA GSL, ROCHA M, BARBOSA JR \& BERROCAL J. 2004. Seismic studies of the Brasilia fold belt at the western border of the São Francisco Craton, Central Brazil, using receiver function, surface-wave dispersion and teleseismic tomography. Tectonophysics, 388 (1-4): 173-185. doi: 10.1016/j.tecto.2004.04.029.

ASSUMPÇÃO M, ARDITO J \& BARBOSA JR. 2010. An Improved Velocity Model For Regional Epicentre Determination in Brazil. In: IV Simpósio Brasileiro de Geofísica. Brasília, 2010, CD-ROM.

BASSIN C, LASKE G \& MASTERS G. 2000. The current limits of resolution for surface wave tomography in North America. EOS Trans AGU, 81: 897.

BERROCAL J, MARANGONI Y, SÁ NC, FUCK RA, SOARES JEP, DANTAS E, PEROSI F \& FERNANDES C. 2004. Deep seismic refraction and gravity crustal model and tectonic deformation in Tocantins province, central Brazil. Tectonophysics, 388 (1-4): 187-199.

BERTEUSSEN KA. 1977. Moho depth determinations based on spectral ratio analysis of norsar long-period $P$ waves. Phys. Earth Planet. Inter., 31: 313-326.

BIANCHI MB. 2008. Variações da estrutura da crosta, litosfera e manto para a plataforma sul americana através de funções do receptor para ondas P e S. Doctore thesis on Geophysics. Programa de Pós-graduação em Geofísica, Universidade de São Paulo, São Paulo, SP, Brasil. 133 p.

CHRISTENSEN I \& MOONEY WD. 1995. Seismic velocity structure and composition of the continental crust: A global view. J. Geophys. Res., 100: 9671-9788.

CORDANI UG, SATO K, TEIXEIRA W, TASSINARI CCG \& BASEI MAS. 2000. Tectonic Evolution of South America. In: $31^{\text {st }}$ International Geological Congress, Rio de Janeiro, Ch. Crustal evolution of the South American Platform., $854 \mathrm{p}$.

DOHERTY J. 2005. Model-independent parameter estimation. Watermark numerical computing. Available on:

<http://www.pesthomepage.org/Home.php>. Acess on: Feb. 18, 2011.

FRANÇA GSLA. 2003. Estrutura da crosta no Sudeste e Centro-0este do Brasil, usando Função do Receptor. Doctore thesis on Geophysics.
Programa de Pós-graduação em Geofísica, Universidade de São Paulo, São Paulo, SP, Brasil. 143 p.

FRANÇA GS \& ASSUMPÇÃO M. 2004. Crustal structure of the Ribeira fold belt, SE Brazil, derived from receiver function. J. South Am. Earth Sc., 16: 743-758.

FUCK RA, DANTAS EL, SORDI DA, CHIARINI MFN \& OLIVEIRA CG. 2007. Folha Santa Terezinha de Goiás - SD.22-Z-A-III, escala 1:100.000. Nota explicativa. UnB, CPRM, PGB/LGB, Brasília.

FUCK RA, PIMENTEL MM, DANTAS EL, OLIVEIRA CG, JUNGES SL \& LAUX JH. 2009. Evolution of the Continental Crust, Abstract Book. Geological Society of London, Jane Watson Meeting: Ch. Episodic crust forming events recorded in the Goiás Magmatic Arc, central Brazil: tectonic implications to Neoproterozoic crustal growth. $33 \mathrm{p}$.

GOLDSTEIN P, DODGE D, FIRPO M \& LEE M. 2003. SAC2000: Signal processing and analysis tools for seismologists and engineers, Invited contribution to The IASPEI International Handbook of Earthquake and Engineering Seismology. Academic Press, editor W.H.K. Lee and H. Kanamori and P.C. Jennings and C. Kisslinger, London.

HERRMANN RB \& AMMON CJ. 2002. Computer programs in seismology. Available on:

$<$ http://www.eas.slu.edu/People/RBHerrmann/CPS330.html>. Access on: Dec. 2011.

HOLBROOK WS, MOONEY WD \& CHRISTENSEN NI. 1992. Continental lower crust. Elsevier, New York, Ch. The seismic velocity structure of the deep continental crust, pp. 1-43.

KENNETT BLN. 1983. Seismic Wave Propagation in Stratified Media. Cambridge University Press, Cambridge. 497 p.

LANGSTON CA. 1977. The effect of planar dipping structure on source and receiver responses for constant ray parameter. Bull. Seism. Soc. Am., 67: 1029-1050.

LANGSTON CA. 1979. Structure under Mount Rainier, Washington, inferred from teleseismic body waves. J. Geophys. Res., 85: 4749-4762.

LEVENBERG K. 1944. A method for the solution of certain non-linear problems in least squares. Q. Appl. Math. 2: 164-168.

LIGORRÍA JP \& AMMON CJ. 1999. Iterative deconvolution and receiver function estimation. Bull. Seism. Soc. Amer., 89: 1395-1400.

LLOYD LS, VAN DER LEE S, FRANÇA GS, ASSUMPÇÃO M \& FENG M. 2010. Moho map of South America from receiver functions and surface waves. J. Geophys.Res. 115: B11315.

MARQUARDT DW. 1963. An algorithm for least-squares estimation of non-linear parameters. J. of the Soc. of Industrial and Applied Mathematics, 11(2): 431-441.

NOVO BARBOSA MF. 2008. Estimativa da espessura crustal na Província Borborema (NE-Brasil) através de Função do Receptor. Master dissertation on Geophysics. Programa de Pós-graduação em Geofísica e 
Geodinâmica. Universidade Federal of Rio Grande do Norte, Natal, RN, Brasil. $66 \mathrm{p}$.

OWENS TJ, ZANDT G \& TAYLOR SR. 1984. Seismic evidence for an ancient rift beneath the Cumberland plateau, Tennessee: a detailed analysis of broadband teleseismic P waveform. J. Geophys. Res., 89: 7783-7795.

OWEN TJ, TAYLOR SR \& ZANDT G. 1987. Crustal structure at regional seismic test network stations determined from inversion of broadband teleseismic p waveforms. Bull. Seism. Soc. Am., 77: 631-632.

PAVÃO CG. 2010. Estudo de Descontinuidades Crustais na Província Borborema usando a Função do Receptor. Master dissertation on Geophysics. Programa de Pós graduação em Geociências Aplicadas, Universidade de Brasília, Brasília, DF, Brazil, 124 p.

PIMENTEL MM, FUCK RA, JOST H, FERREIRA FILHO CF \& ARAÚJO SM. 2000. Tectonic Evolution of South America. $31^{\text {st }}$ International Geological Congress, Rio de Janeiro, Ch. The basement of the Brasilia fold belt and the Goiás Magmatic Arc., $854 \mathrm{p}$.

PIMENTEL MM, JOST H \& FUCK RA. 2004. Geologia do Continente Sul-Americano: evolução da obra de Fernando Flávio Marques de Almeida. Editora Beca, São Paulo, Ch. 0 embasamento da Faixa Brasília e o Arco Magmático de Goiás., 673 p.
SCHIMMEL M \& PAULSSEN H. 1997. Noise reduction and detection of weak, coherent signals through phase-weighted stacks. Geophys. J. Int., 130: 497-505

SOARES JE, BERROCAL J, FUCK RA, MOONEY WD \& VENTURA DBR. 2006. Seismic characteristics of central Brazil crust and upper mantle: A deep seismic refraction study. J. Geophys. Res., 111: B12302. doi: 10.1029/2005JB003769.

VENTURA DBR. 2010. Parâmetros elásticos da crosta sob a linha de refração sísmica profunda de Porangatu (G0). Master dissertation on Geophysics. Programa de Pós-graduação em Geociências Aplicadas, Universidade de Brasília. 161 p.

WESSEL P \& SMITH WHF. 1991. Free software helps map and display data. EOS Trans AGU, 445-446.

ZANDT G \& AMMON CJ. 1995. Continental crust composition constrained by measurements of crustal Poisson's ratio. Nature, 374(6518): 152-154. doi: 10.1038/374152a0.

ZHU L \& KANAMORI H. 2000. Moho depth variation in southern California from teleseismic receiver functions. J. Geophys. Res., 105(B2): 2969-2980. doi: 10.1029/1999JB900322.

\section{NOTES ABOUT THE AUTHORS}

Patrícia Fernandes do Nascimento. Graduated in Geology (2011) and Mathematics (2006) from the Universidade de Brasília and M.Sc. in Geosciences, specifically in Applied Geophysics from the Universidade de Brasília (2011). Currently, works at Petrobras S.A.

George Sand França. Graduated in Physics from the Universidade Federal do Rio Grande do Norte (1996), M.Sc. in Geophysics from the UFRN (1999) and Ph.D. from the Universidade de São Paulo (2003). Currently, is a Professor at the Observatório Sismológico of the Instituto de Geociências of Universidade de Brasília and was awarded a CNPq productivity grant. Areas of interest: natural and induced seismicity, study of the lithosphere and instrumentation for teaching Geosciences.

Lucas Paes Moreira. Bachelor and M.Sc. in Electrical Engineering from the Universidade de Brasília (UnB) and Ph.D. in Geoscience from the Universidade de Brasília. Worked in the installation, operation and maintenance of seismographic and infra-sound stations at the Observatório Sismológico, UnB. Currently, is a Research at the Universidade de Brasília and Professor at the Universidade Católica de Brasília.

Mônica Giannocaro Von Huelsen. Graduated in Geophysics from the Instituto de Astronomia, Geofísica e de Ciências Atmosféricas of the Universidade de São Paulo (IAG-USP) in 1991. M.Sc. in Geophysics from the same institution with the thesis "Mecanismo Focal de João Câmara" (1993). Ph.D. in Geology from the Instituto de Geociências of Universidade de Brasilia, with the thesis "Interpretação de dados de eletromagnetometria aerotransportada (AEM) do sistema GEOTEM no (domínio do tempo)"; worked as visitor professor at the Universidade de Brasília (1993-1995 and 2008-2009), technical manager at Hgeolntergeo (2005-2007). Currently is a Professor at the Instituto de Geociências of Universidade de Brasília (2009). 